\title{
PENERAPAN MODEL PEMBELAJARAN STUDENT TEAMS ACHIEVEMENT DIVISION(STAD) DILENGKAPI LKS UNTUK MENINGKATKAN INTERAKSI SOSIAL DAN PRESTASI BELAJAR SISWA PADA MATERI TERMOKIMIA KELAS XI IPA SMA ISLAM 1 SURAKARTA TAHUN PELAJARAN 2016/2017
}

\author{
Dewi Ponco Wati ${ }^{*}$, Sri Yamtinah, dan Mohammad Masykuri \\ Program Studi Pendidikan Kimia, FKIP, Universitas Sebelas Maret, Surakarta, Indonesia
}

*Keperluan korespondensi, hp: +62896 54210144 e-mail: dewiponcowati@student.uns.ac.id

\begin{abstract}
ABSTRAK
Penelitian ini bertujuan untuk: (1) meningkatkan interaksi sosial siswa pada materi termokimia melalui penerapan model pembelajaran Student Teams Achievement Division (STAD) dilengkapi LKS kelas XI IPA di SMA Islam 1 Surakarta tahun pelajaran 2016/2017 dan (2) meningkatkan prestasi belajar siswa pada materi termokimia melalui penerapan model pembelajaran Student Teams Achievement Division (STAD) dilengkapi LKS kelas XI IPA di SMA Islam 1 Surakarta tahun pelajaran 2016/2017. Penelitian ini merupakan penelitian tindakan kelas yang terdiri dari dua siklus, dimana masing-masing siklus meliputi, perencanaan, pelaksanaan, observasi, dan refleksi. Subyek penelitian ini adalah siswa kelas XI IPA SMA Islam 1 Surakarta tahun pelajaran 2016/2017. Data yang diperoleh berupa prestasi belajar (aspek kognitif dan aspek afektif) dan interaksi sosial siswa. Sumber data adalah guru dan siswa. Teknik pengumpulan data adalah dengan tes, angket, observasi, dan wawancara, selanjutnya data dianalisis secara deskriptif kualitatif. Hasil penelitian menunjukkan bahwa, (1) penerapan model pembelajaran Student Teams Achievement Division (STAD) dilengkapi LKS dapat meningkatkan interaksi sosial siswa pada materi termokimia di kelas XI IPA SMA Islam 1 Surakarta tahun pelajaran $2016 / 2017$. Interaksi sosial siswa pada pra-tindakan sebesar $55 \%$ meningkat menjadi $75 \%$ pada siklus I. (2) penerapan model pembelajaran Student Teams Achievement Division (STAD) dilengkapi LKS dapat meningkatkan prestasi belajar siswa pada materi termokimia di kelas XI IPA SMA Islam 1 Surakarta tahun pelajaran 2016/2017. Aspek kognitif siswa pada siklus I sebesar $20 \%$ meningkat menjadi $80 \%$ pada siklus II. Aspek afektif mencapai 100\% pada siklus I dan tidak dilanjutkan pada siklus II.
\end{abstract}

Kata kunci: Penelitian Tindakan Kelas, STAD, LKS, Interaksi Sosial Siswa, Prestasi Belajar

\section{PENDAHULUAN}

Pembelajaran kimia merupakan suatu proses yang dilakukan oleh individu untuk memperoleh suatu perubahan tingkah laku sebagai hasil pengalaman berdasarkan fakta-fakta yang didapatkan dari pengamatan. Kimia merupakan pelajaran yang sulit karena menyangkut tiga tingkat pemikiran, yaitu makro, submikro, dan simbol [1]. Kimia merupakan salah satu mata pelajaran yang masuk dalam struktur kurikulum SMA/MA kelas X, SMA/MA kelas XI dan XII program IPA.
Kurikulum yang saat ini diterapkan di Indonesia adalah Kurikulum Tahun 2006 (KTSP) dan Kurikulum 2013. Dalam pelaksanaan Kurikulum Tahun 2006, guru sebagai pendidik harus menempatkan siswa sebagai subjek didik sehingga proses pembelajaran lebih berpusat pada siswa (student centered).

SMA Islam 1 Surakarta merupakan salah satu sekolah yang menerapkan Kurikulum Tahun 2006. Berdasarkan hasil pengamatan di kelas dan wawancara dengan guru mata pelajaran kimia, diketahui bahwa banyak siswa 
mengalami kesulitan dalam mempelajari kimia. Siswa merasa pelajaran kimia abstrak dan sulit dipahami. Salah satu materi kimia yang dianggap sulit oleh siswa adalah termokimia. Termokimia menangani pengukuran dan penafsiran perubahan kalor yang menyertai reaski kimia, perubahan keadaan, dan pembentukan larutan [2]. Berdasarkan hasil wawancara dengan guru mata pelajaran kimia, kesulitan yang sering dialami siswa dalam mempelajari materi termokimia, antara lain membedakan reaksi pembentukan dan penguraian dan menuliskan rumus kimia beserta gambar ikatan untuk menentukan $\Delta \mathrm{H}$ reaksi.

Faktor internal yang bisa menjadi penyebab kesulitan siswa dalam mempelajari materi termokimia, antara lain tingkat kecerdasan, motivasi belajar, aktivitas belajar, dan interaksi sosial. Interaksi sosial adalah suatu hubungan antara 2 individu atau lebih, di mana kelakuan individu yang satu mempengaruhi, mengubah, atau memperbaiki kelakuan individu yang lain atau sebaliknya [3]. Aspek yang dinilai pada interaksi social, antara lain kerja sama, persaingan, pertentangan, persesuaian, dan perpaduan. Menurut keterangan dari guru mata pelajaran kimia, ketika dilaksanakan diskusi secara berkelompok dalam proses pembelajaran kimia, siswa cenderung bergantung dan mengandalkan siswa yang lebih pintar. Siswa tidak merasa bertanggungjawab terhadap tugas kelompok yang diberikan oleh guru. Salah satu faktor eksternal yang mampu menjadi penyebab kesulitan yang dialami siswa adalah metode pembelajaran yang digunakan oleh guru dalam menyampaikan materi. Berdasarkan penuturan guru mata pelajaran kimia, selama ini metode yang digunakan dalam proses belajar mengajar adalah ceramah, mengakibatkan kegiatan yang dilakukan siswa selama pembelajaran berlangsung hanyalah mendengarkan dan mencatat.

Sebuah model pembelajaran kooperatif yang berpusat pada siswa diperlukan untuk mengatasi kesulitan tersebut. Pembelajaran kooperatif adalah solusi ideal terhadap masalah menyediakan kesempatan berinteraksi secara kooperatif dan tidak dangkal kepada para siswa [4]. Penggunaan pembelajaran kooperatif dalam kegiatan belajar mengajar dapat meningkatkan prestasi belajar dan daya ingat dari siswa [5]. Salah satu model pembelajaran kooperatif sederhana yang dapat diterapkan adalah Student Teams Achievement Division (STAD). Gagasan utama di balik model STAD adalah untuk memotivasi para siswa, mendorong, dan membantu satu sama lain, dan untuk menguasai keterampilan-keterampilan yang disajikan oleh guru [6]. Keunggulan dari model pembelajaran STAD adalah setiap siswa memiliki tanggung jawab atas keberhasilan kelompoknya, sehingga tidak hanya bergantung pada beberapa siswa yang pandai saja. Penerapan model pembelajaran STAD dilengkapi media Log Book Chemistry dapat meningkatkan prestasi belajar siswa pada materi koloid [7]. Penerapan model pembelajaran STAD dapat meningkatkan prestasi belajar siswa pada materi kesetimbangan[8].

Pemilihan media pembelajaran yang sesuai dengan karakteristik materi dan model pembelajaran dapat membantu siswa dalam mempelajari materi yang diajarkan. Media yang sesuai dengan karakteristik materi termokimia adalah Lembar Kerja Siswa (LKS). Lembar Kerja Siswa (LKS) merupakan perangkat pembelajaran berupa lembaran kertas yang berisi informasi maupun soal-soal yang harus dikerjakan oleh siswa [9]. Penggunaan LKS mampu meningkatkan prestasi belajar siswa pada materi stoikiometri [10].

Berdasarkan uraian tersebut, maka dilakukan penelitian mengenai penerapan model pembelajaran STAD dilengkapi LKS untuk meningkatkan interaksi social dan prestasi belajar siswa pada materi termokimia kelas XI IPA SMA Islam 1 Surakarta Tahun Pelajaran 2016/2017.

\section{METODE PENELITIAN}

Penelitian ini merupakan penelitian tindakan kelas yang terdiri dari dua siklus, dimana masing-masing siklus 
meliputi, perencanaan, pelaksanaan, observasi, dan refleksi [11].

Subjek penelitian adalah siswa kelas XI IPA semester ganjil SMA Islam 1 Surakarta tahun pelajaran 2016/2017. Pemilihan siswa kelas XI IPA SMA Islam 1 Surakarta dalam penelitian ini didasarkan pada permasalahan-permasalahan yang terlah teridentifikasi pada saat observasi awal dan wawancara terhadap guru. Objek penelitian ini adalah kualitas proses dan hasil belajar siswa. Kualitas proses belajar siswa dibatasi pada interaksi sosial yang meliputi kerja sama, pertentangan, persaingan, persesuaian, dan perpaduan. Sedangkan kualitas hasil belajar siswa yaitu prestasi belajar siswa meliputi aspek kognitif dan aspek afektif.

Data penelitian yang dikumpulkan meliputi data pra penelitian dan data penelitian. Data pra penelitian melipui data kesulitan belajar siswa, data kondisi pembelajaran kimia, dan nilai ulangan harian kelas XI IPA semester ganjil tahun pelajaran 2015/2016. Data pra penelitian digunakan sebagai pendukung pelaksanaan penelitian. Sedangkan data penelitian berupa data interaksi sosial siswa dan prestasi belajar siswa yang meliputi aspek kognitif dan afektif siswa kelas XI IPA SMA Islam 1 Surakarta tahun pelajaran 2016/2017 khususnya pada materi termokimia.

Data yang dikumpulkan dalam penelitian ini meliputi data informasi tentang keadaan siswa dilihat dari aspek kualitatif dan kuantitatif. Aspek kualitatif berupa data hasil observasi dan wawancara yang menggambarkan proses pembelajaran di kelas, interaksi sosial siswa, dan kesulitan yang dihadapi guru baik dalam menghadapi siswa maupun cara mengajar di kelas. Aspek kuantitatif yang dimaksud adalah berupa data penilaian prestasi belajar siswa pada materi termokimia yang meliputi aspek kognitif dan afektif baik siklus I maupun siklus II.

Teknik analisis data menggunakan analisis deskriptif kualitatif. Analisis data menggunakan triangulasi data yang terdiri dari tiga tahapan, yaitu reduksi data, pemaparan data, dan penarikan kesimpulan [12].

\section{HASIL DAN PEMBAHASAN}

Kondisi awal pembelajaran kimia diketahui berdasarkan hasil observasi dan wawancara terhadap guru mata pelajaran kimia. Pada kondisi awal, siswa mengalami kesulitan dalam mempelajari materi termokimia yang berisi konsep dan hitungan. Interaksi sosial siswa tergolong sedang, bahkan ada yang memiliki interaksi sosial dengan kategori rendah. Penelitian dilaksanakan dalam 2 siklus.

\section{Siklus I}

\section{a. Perencanaan}

Pada tahap perencanaan, peneliti dan guru mata pelajaran kimia mempersiapkan beberapa perangkat penelitian, berupa silabus, Rencana Pelaksanaan Pembelajaran (RPP), dan instrumen penilaian prestasi belajar. Siklus I terdiri dari 5 kali pertemuan untuk menyampaikan materi dan 1 kali untuk evaluasi.

\section{b. Pelaksanaan Tindakan}

Siklus I dilaksanakan pada tanggal 24 Agustus hingga 21 September 2016. Pada tahap awal pembelajaran, siswa dibagi ke dalam kelompok heterogen. Guru menyampaikan materi secara singkat dan memberikan Lembar Kerja Siswa (LKS), kemudian dilanjutkan siswa diskusi secara berkelompok untuk menyelesaikan soal diskusi sesuai dengan materi yang telah disampaikan guru. Diskusi kelompok memberikan kesempatan bagi siswa untuk saling membantu dalam memahami materi yang telah disampaikan. Pemahaman individu terhadap materi sangat berpengaruh terhadap keberhasilan kelompok untuk meraih predikat kelompok terbaik dan mendapatkan reward.

Selama pelaksanaan siklus I siswa masih dalam tahap penyesuaian diri dengan model pembelajaran yang digunakan, namun siswa tidak merasa kesulitan dalam melaksanakan sintaks model pembelajaran STAD karena 
sederhana. Pada akhir pembelajaran, siswa mempresentasikan hasil diskusi kelompoknya yang dilanjutkan dengan konfirmasi dari guru mata pelajaran kimia. Pemahaman siswa terhadap materi yang telah disampaikan dapat diketahui melalui hasil kuis yang diberikan setiap akhir pertemuan.

\section{c. Pengamatan}

Pengamatan terhadap aktivitas siswa dilakukan selama proses pembelajaran berlangsung, dari pertemuan pertama hingga kelima. Data yang diperoleh dalam penelitian ini adalah data interaksi sosial siswa dan prestasi belajar yang meliputi aspek kognitif dan afektif.

Aspek yang dinilai dari interaksi sosial siswa, antara lain kerja sama, persaingan, pertentangan, persesuaian, dan perpaduan. Data interaksi sosial siswa yang diperoleh meliputi data pra tindakan dan data tindakan siklus I, yang terdiri dari data observasi, angket penilaian diri, dan wawancara guru mata pelajaran kimia. Ringkasan hasil pengambilan data interaksi sosial siswa disajikan pada Tabel 1

Tabel 1. Hasil Interaksi Sosial Siswa

\begin{tabular}{lcc}
\hline \multirow{2}{*}{ Kriteria } & \multicolumn{2}{c}{ Ketercapaian (\%) } \\
\cline { 2 - 3 } & $\begin{array}{c}\text { Pra } \\
\text { tindakan }\end{array}$ & Siklus I \\
\hline Tinggi & 55 & 75 \\
Sedang & 45 & 25 \\
Rendah & 0 & 0 \\
\hline
\end{tabular}

Target interaksi sosial siswa adalah $75 \%$ memiliki kriteria tinggi. Hasil pra tindakan menunjukkan bahwa baru $55 \%$ siswa memiliki interaksi sosial tinggi sehingga diperlukan penilaian pada siklus I setelah diterapkan model pembelajaran STAD dilengkapi LKS. Hasil penilaian interaksi sosial siswa pada siklus I menunjukkan bahwa sebanyak $75 \%$ siswa memiliki interaksi sosial tinggi dan $25 \%$ sedang. Pelaksanaan diskusi dalam penerapan model pembelajaran STAD memberikan kesempatan kepada siswa untuk saling berinteraksi dan membantu dalam memahami materi pembelajaran.
Adanya presentasi hasil diskusi dan konfirmasi guru memberikan kesempatan untuk meningkatkan interaksi sosial antara siswa dan guru.

Data prestasi belajar aspek kognitif siswa diambil pada akhir siklus I berupa tes obyektif. Ringkasan hasil pengambilan data prestasi belajar aspek kognitif siswa pada siklus I disajikan pada Tabel 2.

Tabel 2. Hasil Belajar Aspek Kognitif Siswa Pasca Siklus I

\begin{tabular}{lc}
\hline \multicolumn{1}{c}{ Kriteria } & Ketercapaian (\%) \\
\hline Tuntas & 20 \\
Belum Tuntas & 80 \\
\hline
\end{tabular}

Target untuk prestasi belajar aspek kognitif yaitu $70 \%$ siswa mencapai ketuntasan dengan KKM 72. Hasil dari siklus I menunjukkan masih diperlukan perbaikan terhadap pembelajaran yang dilaksanakan agar ketuntasan belajar siswa meningkat. Oleh karena itu, dilakukan serangkaian perencanaan untuk pelaksanaan siklus II.

Data prestasi belajar aspek afektif didapatkan berdasarkan observasi selama pembelajaran, angket penilaian diri siswa, dan wawancara guru mata pelajaran kimia. Aspek yang dinilai pada prestasi belajar afektif siswa, antara lain sikap, minat, konsep diri, nilai, dan moral. Ringkasan hasil pengambilan data prestasi belajar aspek afektif siswa disajikan pada Tabel 3.

Tabel 3. Ringkasan Hasil Belajar Aspek Afektif Siswa

\begin{tabular}{lcc}
\hline \multirow{2}{*}{ Kriteria } & \multicolumn{2}{c}{ Ketercapaian (\%) } \\
\cline { 2 - 3 } & $\begin{array}{c}\text { Pra } \\
\text { tindakan }\end{array}$ & Siklus I \\
\hline Sangat Baik & 5 & 15 \\
Baik & 90 & 85 \\
Kurang & 5 & 0 \\
Sangat & 0 & 0 \\
Kurang & 0 \\
\hline
\end{tabular}

Target untuk prestasi belajar aspek afektif adalah $75 \%$ siswa memiliki kriteria baik. Hasil pra tindakan menunjukkan $90 \%$ siswa memiliki kriteria baik, namun terdapat $5 \%$ siswa dengan kriteria 
kurang sehingga perlu dilakukan penilaian pada siklus I. Hasil siklus I menunjukkan bahwa 100\% siswa telah memiliki prestasi belajar aspek afektif dengan kriteria baik. Target untuk prestasi belajar aspek afektif telah tercapai sehingga tidak dilakukan penilaian pada siklus II.

\section{d. Refleksi}

Berdasarkan hasil evaluasi pada siklus I, perlu dilakukan tindakan untuk memperbaiki proses pembelajaran materi Temokimia dengan model STAD. Pelaksanaan tindakan siklus II bertujuan untuk meningkatkan prestasi belajar siswa pada aspek kognitif karena masih ada beberapa indikator yang memiliki persentase di bawah target. Sakah satu indikator soal dengan persentase ketuntasan paling rendah pada siklus I adalah menghitung $\Delta \mathrm{H}$ reaksi yang diinginkan, jika diberikan data mengenai energi ikatan rata-rata dari beberapa molekul. Rendahnya persentase ketuntasan siswa diakibatkan oleh siswa belum sepenuhnya paham dengan konsep perhitungan $\Delta \mathrm{H}$ reaksi berdasarkan energi ikatan.

Pelaksanaan siklus II berbeda dengan siklus I, dimana kelompok diskusi dibagi berdasarkan hasil evaluasi aspek kognitif siklus I dengan anggota masing-masing kelompok 4 siswa agar diskusi lebih efisien. Perbedaan lainnya adalah, soal yang digunakan untuk evaluasi aspek kognitif siklus II merupakan soal yang telah dibuat dan dimodifikasi oleh penulis sedekimian rupa pada indikator yang belum tercapai saja.

\section{Siklus II}

\section{a. Perencanaan}

Pelaksanaan siklus II direncanakan berdasarkan hasil refleksi pelaksanaan siklus I. Berdasarkan hasil siklus I, diketahui bahwa hasil interaksi sosial siswa dan prestasi belajar aspek afektif telah mencapai target dan mengalami peningkatan dari data pratindakan. Pada siklus II hanya dilakukan penilaian terhadap prestasi belajar siswa aspek kognitif terhadap indikator kompetensi yang belum tuntas pada siklus I.

Siklus II pada penelitian ini terdiri dari 1 kali pertemuan untuk pendalaman materi dan 1 kali untuk evaluasi. Materi yang disampaikan pada siklus II merupakan materi pada indikator kompetensi yang belum tuntas pada evaluasi siklus I. Terdapat 6 indikator kompetensi yang belum tercapai pada siklus I, antara lain menjelaskan perubahan entalpi $(\Delta \mathrm{H})$ sebagai kalor reaksi pada tekanan tetap, menjelaskan macam-macam perubahan entalpi, menghitung harga $\Delta \mathrm{H}$ reaksi berdasarkan data percobaan, data entalpi pembentukkan standar $\left(\Delta \mathrm{H}_{\mathrm{f}}^{\circ}\right)$, hukum Hess, dan data energi ikatan.

\section{b. Pelaksanaan Tindakan}

Pembelajaran dimulai dengan guru menjelaskan secara singkat materi yang belum tuntas pada evaluasi siklus I dan dilanjutkan dengan pengerjaan contoh soal untuk memperdalam pemahaman siswa. Siswa diberi kesempatan untuk bertanya mengenai soal pada evaluasi siklus I yang dirasa sulit. Pembelajaran dilanjutkan dengan pelaksanaan diskusi kelompok.

Pada pelaksanaan siklus II, kelompok diskusi siswa diatur kembali menjadi kelompok lebih kecil berdasarkan hasil siklus I. Kelompok diskusi yang lebih kecil membuat diskusi yang dilaksanakan lebih efisien. Pelaksaan diskusi berjalan dengan kondusif, dimana antar anggota kelompok saling membantu dalam memahami materi. Jika dibandingkan dengan siklus I siswa lebih sering bertanya kepada guru apabila belum paham. Pada akhir pembelajaran dilaksanakan kuis untuk mengetahui pemahaman siswa.

\section{c. Pengamatan}

Pengamatan pada siklus II terpusat pada aspek kognitif siswa. Penilaian terhadap aspek kognitif siswa dilaksanakan pada akhir siklus berupa soal pilihan ganda yang terdiri dari 15 butir soal pada indikator yang belum tercapai di siklus I. 
Ringkasan hasil pengambilan data prestasi belajar aspek kognitif siswa pada siklus II disajikan pada Tabel 4.

Tabel 4. Hasil Belajar Aspek Kognitif Siswa Pasca Siklus II

\begin{tabular}{lc}
\hline \multicolumn{1}{c}{ Kriteria } & Ketercapaian (\%) \\
\hline Tuntas & 80 \\
Belum Tuntas & 20 \\
\hline
\end{tabular}

Hasil aspek kognif siswa pada siklus II menunjukan peningkatan persentase ketuntasan siswa sebesar $60 \%$ dari $20 \%$ pada siklus I meningkat menjadi $80 \%$ pada siklus II. Peningkatan persentase pada tiap indikator kompetensi menunjukkan bahwa pelaksanaan tindakan siklus II dapat memperbaiki masalah yang muncul pada siklus I. Kelompok diskusi siklus II dibagi secara heterogen berdasarkan hasil tes aspek kognitif siklus I. Siswa yang memiliki pemahaman lebih dapat membagikan pengetahuan yang dimiliki kepada siswa lain.

\section{d. Refleksi}

Pada pelaksanaan siklus II, guru menekankan pada materi yang belum dikuasai siswa. Kelompok diatur sedemikian rupa berdasarkan hasil evaluasi siklus I sehingga diskusi berjalan lebih kondusif dan mampu memunculkan interaksi antar siswa. Siswa yang lebih pandai dapat membantu teman lain untuk memahami materi.

Interaksi-interaksi seseorang dengan orang lain yang memiliki tingkat intelektual yang lebih tinggi dapat membantu pembelajaran [13]. Selain itu, apa yang dikerjakan siswa dengan cara bekerja sama dengan orang yang berkompeten pada hari ini, siswa tentu dapat melakukannya sendiri besok pagi [14].

Hasil yang diperoleh berdasarkan evaluasi pada akhir siklus II menunjukkan bahwa penerapan model pembelajaran STAD dilengkapi LKS mampu meningkatkan prestasi belajar aspek kognitif siswa, dari $20 \%$ siswa tuntas pada siklus I naik menjadi $80 \%$ pada siklus II.

\section{Perbandingan Antar Siklus}

Perbandingan antar siklus dilakukan untuk mengetahui perbedaan hasil yang didapatkan pada pra-tindakan, siklus I, dan siklus II.

Pada pembelajaran STAD dilengkapi LKS terjadi peningkatan hasil, baik dari pra tindakan, siklus I, ataupun siklus II. Perbandingan hasil dapat dilihat pada Gambar 1.

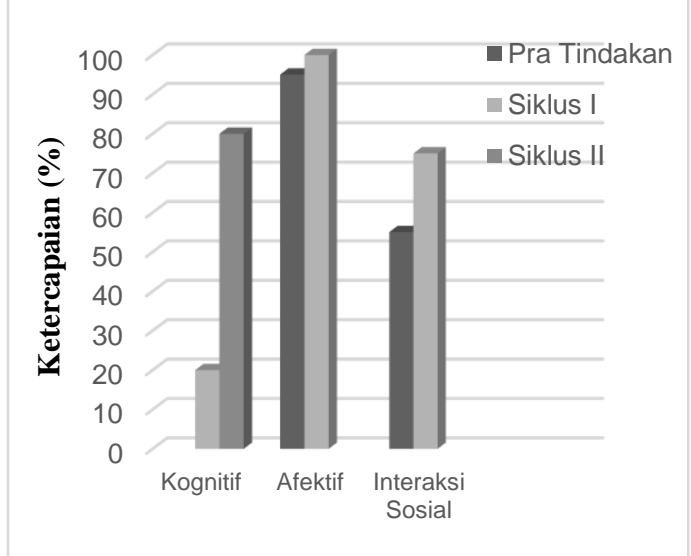

Gambar 1. Histogram pencapaian prestasi belajar aspek kognitif, aspek afektif, dan interaksi sosial

Berdasarkan hasil yang telah dipaparkan, secara keseluruhan dapat dilihat bahwa penelitian model pembelajaran STAD dilengkapi LKS pada materi termokimia kelas XI IPA SMA Islam 1 Surakarta tahun pelajaran 2016/2017 mampu meningkatkan prestasi belajar berupa aspek kognitif dan aspek afektif, serta meningkatkan interaksi sosial siswa.

\section{KESIMPULAN}

Berdasarkan hasil penelitian dapat disimpulkan bahwa penerapan model pembelajaran Student Teams Achievement Division (STAD) dilengkapi LKS dapat meningkatkan prestasi belajar dan interaksi sosial siswa pada materi termokimia di kelas XI IPA SMA Islam 1 Surakarta tahun pelajaran 2016/2017. Aspek kognitif siswa pada siklus I sebesar $20 \%$ meningkat menjadi $80 \%$ pada siklus II. Aspek afektif mencapai $100 \%$ pada siklus I dan tidak dilanjutkan pada siklus II. Interaksi sosial siswa pada pra-tindakan sebesar 55\% meningkat menjadi $75 \%$ pada siklus I. 


\section{UCAPAN TERIMA KASIH}

Penelitian ini tidak dapat diselesaikan tanpa adanya dukungan dari berbagai pihak. Dalam kesempatan ini, peneliti mengucapkan terima kasih dan penghargaan yang tulus kepada Bapak Drs. Sudadi Wahyono selaku Kepala SMA Islam 1 Surakarta yang telah memberikan izin untuk mengadakan penelitian di lingkungan SMA Islam 1 Surakarta. Kepada Ibu Dwidjajanti, S.Pd., selaku guru mata pelajaran kimia SMA Islam 1 Surakarta yang telah mengizinkan peneliti untuk menggunakan kelasnya dalam penelitian ini.

\section{DAFTAR RUJUKAN}

[1] Johnstone, A. H., (2006). Chemical education research in Glasgow in perspective. Chemistry Education and Practice, 7(2): 49 - 63.

[2] Keenan, Kleinfelter, dan Wood. (1990). Kimia Untuk Universitas. Terj. A. Handayana Pudjaatmaka. Jakarta: Erlangga.

[3] Ahmadi, A. (1999). Psikologi Sosial. Jakarta: PT Rineka Cipta.

[4] Slavin, R. E. (2005). Cooperative Learning. Terj.Narulita Yusron. Bandung: Penerbit Nusa Media.

[5] Tran, V. D. (2014). The Effect of Cooperative Learning on The Academic Achievement and Knowledge Retention. International Journal of Higher Education, 3 (2), 131-140

[6] Shoimin, A. (2014). 68 Model Pembelajaran Inovatif dalam Kurikulum 2013. Yogyakarta: Arruzz Media.

[7] Pratama, W., Agung N.C.S., Bakti M. (2015). Penerapan Metode Pembelajaran Student Teams Achievement Division (STAD) dilengkapi Log Book Chemistry (Log-Chem) untuk Meningkatkan Kemandirian dan Prestasi Belajar Siswa pada Materi Koloid Kelas XI MIA SMA Negeri 1 Banyudono Tahun Pelajaran 2014/2015. Jurnal
Pendidikan Kimia (JPK), 4 (4) 180185

[8] Hidayati, I.N.A., Tri R., Budi H. (2013). Penerapan Model Pembelajaran Kooperatif Tipe Student Teams Achievement Division (STAD) untuk Meningkatkan Aktivitas dan Prestasi Belajar Kimia pada Materi Pokok Kesetimbangan Kimia Siswa Kelas XI MAN Klaten Tahun Pelajaran 2011/2013. Jurnal Pendidikan Kimia (JPK), 2 (2) 92-99

[9] Hamdani. (2011). Strategi Belajar Mengajar. Bandung: Pustaka Setia

[10] Nuriyawan, H., Ashadi, Widiastuti A. E.S. (2016). Penerapan Model Pembelajaran Problem Posing dilengkapi Media Pembelajaran Lembar Kerja Siswa (LKS) untuk Meningkatkan Prestasi Belajar dan Kemampuan Proses Sains Siswa pada Materi Stoikiometri Kelas X Semester Genap SMA Negeri 1 Sukoharjo Tahun Pelajaran 2015/2016. Jurnal Pendidikan Kimia (JPK), 5 (3) 77-86

[11] Kunandar. (2011). Langkah Mudah Penelitian Tindakan Kelas Sebagai Pengembangan Profesi Guru. Jakarta: PT RajaGrafindo Persada.

[12] Gunawan, I. (2014). Metode Penelitian Kualitatif: Teori dan Praktik. Jakarta: PT Bumi Aksara.

[13] Schunk, D. H. (2012). Learning Theories An Educational Perspective. Terj.Eva Hamdiah, Rahmat Fajar. Yogyakarta: Pustaka Pelajar.

[14] Suyono dan Hariyanto. (2012). Belajar dan Pembelajaran Teori dan Konsep Dasar. Bandung: PT Remaja Rosdakarya. 